\title{
Religious education as a dialogue with difference: Fostering democratic citizenship through the
}

study of religions in schools, by Kevin O'Grady, Abingdon, Routledge, 2019, 200 pp., $£ 105$ (hardback), ISBN: 978-1-138-47992-0

An important current issue in education is how to support teachers' engagement in and with research. But if teachers were research-engaged, what would this look like? With a thirty-three year career in education, Kevin O'Grady's book offers an illuminating example of how researchengagement provides the catalyst for thoughtful and insightful reflections on religious education, current schooling and contemporary research, written 'as a contribution to debates over how religion should be studied in schools' (p. 1). Its structure is essentially his intellectual autobiography over nineteen years as a teacher and researcher in religious education, particularly through action research in his own classroom, but also in other collaborations. He narrates his various research interests and projects in order to build up an argument for the title's vision, and then goes on to critique and examine other research.

In the Introduction he outlines the book's aims and structure and explains some of the wider contextual issues for religious education in England - particularly as the book is part of a US edited series. The following chapters are largely drawn from earlier published work, and Chapters One and Two outline his first action research project, based on his Master's research at Warwick, with Eleanor Nesbitt and Robert Jackson. These chapters focus on motivation, drawing on, and seeking to synthesise, Jackson's interpretive approach to religious education with theories of adolescence and creativity by arguing that identity development through religious education is synonymous with democratic citizenship. The next three chapters explore his doctoral studies at Warwick. Chapter Three builds on the previous chapters to address the relevance and value of action research methodology, and then he explores the book's central themes of religious education as a 'dialogue with difference' in Chapter Four, which he describes as the 'narrative heart of the book' (p. 75), and 
'democratic citizenship or religious literacy?' in Chapter Five, where he considers his findings in relation to Andrew Wright's work.

The next three chapters move through later research projects, first, REDCo ('Religion in Education: Dialogue or Conflict?'- see Weisse 2007), and a related community of practice in action research (of which I was a part - see Ipgrave et al. 2009) that sought to explore issues of pedagogy and classroom dialogue in various educational settings. He then (Chapter Seven) draws on this to comment on and critique Barnes's rejection of the inclusion of worldviews in religious education, and Gearon's view that current religious education has lost contact with the sacred. This sequence of chapters ends (Chapter Eight) with a reflection on the 'Does RE Work?' project (Conroy et al. 2013), agreeing with their claims that pluralism and performative examinations have reduced the subject's vitality. Finally, a concluding chapter offers some questions and remarks for the future of the subject, and restating the interrelationship between religious education, dialogue and citizenship.

In addressing concerns with rigour, O'Grady alludes to a remark by Hans-Gunther Heimbrock, who described his research as a 'fruitful irritation' (p.4). This book is much more. Its significance is as a sustained account of engagement in and with research in religious education by a teacherresearcher, in showing how a series of different projects can develop into a vision of both the subject and of research-engaged practice. Here is someone who was simultaneously teaching in a secondary school in Sheffield and addressing the work of Csikscentmihalyi on creativity, Cotterell on adolescence, as well as Barnes, Gearon and Wright on contemporary religious education. In this, 'craft knowledge' (p. 15) counts for much, as grounds for acceptance or rejection of a particular argument, a professional perspective offering a potential falsification of some philosophical, but unempirical claims.

However, I would pause to reflect on whether the argument fully integrates the individual elements that have been drawn together with the overall claim about the subject as developing 'democratic citizenship through dialogue with difference'. The broad 'post hoc' narrative arc sometimes seems 
to overtake the specifics; thus, the interesting early sections on motivation and creativity do not fully support these later claims. Further, different interpretations of talk seem to be conflated:

Gadamer's hermeneutical model of 'conversation' is not the same as Dewey's democratic 'dialogue' or Vygotskian pedagogical dialogue - even if they may have something in common.

It would be fruitful to see these lines of inquiry developed more, and not least because O'Grady has a sense of the realities and complexities of daily work in school. The book will be of interest to anyone interested in current debates about the place of religious education in society, especially in how these debates play out in classrooms, and in how religious education teachers can also be involved in, comment on and contribute to research.

Conroy, J., D. Lundie, R. Davis, V. Baumfield, L. P. Barnes, T. Gallagher, K. Lowden, N. Bourque, and K. Wenell. 2013. Does RE Work? A Multidimensional Investigation. London: Bloomsbury Ipgrave, J., R. Jackson, and K. O'Grady (eds.) 2009. Religious Education Research through a Community of Practice. Münster: Waxmann

Weisse, W. 2007. “The European Research Project on Religion and Education 'REDCO'. An Introduction." In Religion and Education in Europe: Developments, Contexts and Debates, edited by R. Jackson, S. Miedema, W. Weisse, and J.-P. Willaime, 9-25. Münster: Waxmann

Nigel Fancourt University of Oxford nigel.fancourt@education.ox.ac.uk (C) 2019 Nigel Fancourt 